\title{
Change of the Higher Education Paradigm in the Context of Digital Transformation: From Resource Management to Access Control
}

\author{
Ilshat Rafkatovich Gafurov ${ }^{1}$, Marat Rashitovich Safiullin ${ }^{1}$, Elvir Munirovich Akhmetshin ${ }^{1}$, Almaz Rafisovich \\ Gapsalamov $^{1}$ \& Vladimir Lvovich Vasilev ${ }^{1}$ \\ ${ }^{1}$ Kazan Federal University, Kazan, Russia \\ Correspondence: Elvir Munirovich Akhmetshin, Kazan Federal University, Republic of Tatarstan, 423604, Elabuga, \\ Kazanskaya Street, 89, Russia.
}

Received: January 28, 2020

Accepted: March 4, 2020

Online Published: March 9, 2020

doi:10.5430/ijhe.v9n3p71

URL: https://doi.org/10.5430/ijhe.v9n3p71

\begin{abstract}
Digitalization and transition to a new technological structure bring humanity to another level of development. The changing technological structures, industry and society progress, enhance the importance of improving the university development model. The existing management system and infrastructure in universities are often outdated and unable to ensure their competitive and adequate functioning. Hence, the need to improve the processes of using the university infrastructure through digital technology. The composition and range of the resources should also be reviewed and supplemented with new components.
\end{abstract}

The purpose of this work is to reveal the principles and requirements for improving the university infrastructure using digital technology.

The methodology is based on modeling the university management system, with the concept of infrastructure logic as a core, meant to include new elements in the university management infrastructure: university stakeholders, cultural values, investments and translation.

The management model transformation implies a transition from structural to infrastructural approach, from infrastructure management to managing the infrastructure logic. The digital network platform incorporating the information on all the infrastructure facilities, their status, will provide effective user access management to each university resource.

The recommendations formulated to improve the university infrastructure using digital technology will make higher education more effective.

Keywords: university infrastructure, infrastructure logic, resource management, access control, university development strategy, university digitalization, university digital transformation

\section{Introduction}

\subsection{Research Problem}

Digitalization and transition to a new technological structure lead humanity to a new level of development. The new level of development involves active use of digital technology. In these conditions, the importance of improving the development model of the university is growing (Lezer et al., 2020; Khalid et al., 2018).

As the dynamism of technological structure changes inevitably grows, this then requires modern universities to increase their responsiveness to external and internal changes in the university system, flexibility and adaptability. The existing management systems and infrastructures in many universities often date back to the past era, and therefore are usually not able to ensure the competitive functioning of the university adequate to the new realities. There are completely new requirements for infrastructure management (Holmwood et al., 2019; Hasanović et al., 2012). In order to accelerate the technological development of the university, it is necessary to involve not only all infrastructure objects, but also intellectual and cultural potential. Historically, university infrastructure was mainly focused on the management of material resources such as buildings, structures, equipment, networks, and in current times, in order to solve the tasks of adaptability, flexibility and rate of development, there needs to be a system of cultural values and staff involvement as a tool for coordinated interaction making it possible to interconnect all the components together (Shaik et al., 2020; Rothmann, 2013). Mobilization of a significantly larger number of 
resources requires the improvement of the access control system to the university infrastructure facilities. Therefore, in the management of the university the infrastructure management processes should be revised.

Universities have focused mainly on the development of the resource base: modernizing property, developing communications and attracting personnel (Buyak et al., 2019; Lisyutkin, 2017). At present, the main thing is the sharing of resources of partner universities and the operational, mutually beneficial, network formation of resources for the implementation of scientific and technical projects (Tay \& Low, 2017).

Currently, due to the Internet, all universities globally are working in a single information environment. The solution of modern scientific problems is no longer possible within the framework of one university, but requires the creation of a cooperative scientific network of partner universities. Each university has its own unique infrastructure improving over decades. In the modern context, it is more advisable for universities to use each other's infrastructure to mutual benefit than to spend time and resources to create their own comprehensive infrastructure (Johnson, 2019; Shirokova et al., 2017). The emphasis shifts from competition for resources to cooperation through access to shared resources. Implying a change in the methodology from competitive market relations to cooperative-partner interaction (Bahrani et al., 2019; Courcoubetis et al., 2012). The result of this cooperation can fundamentally change the established paradigms of national innovation systems in general and higher education in particular.

Digital technologies allow a remote use of the laboratory and personnel potential of various universities. Therefore, it is important to ensure safe and mutually beneficial access to university resources using digital technology. Additionally, the composition and range of the resources should be reviewed and supplemented with new components. The infrastructure of a modern university is not only premises, equipment, information services, teachers and researchers, but also cultural values, investments, and access to the benefits of life quality. Adding common cultural values to the infrastructure logic allows the university to ensure the availability of similar values for different groups of university users (Huang et al, 2019; Kalitanyi et al, 2018; Shuter et al, 2018). The modern university actively collaborates with investors: banks, management companies, investment funds, large industrial corporations. These investors provide financial resources for mutually beneficial implementation of scientific and technical projects of the university. Translation of the latest scientific and technological discoveries in practice allows the conversion of scientific and educational competencies into scalable projects in the real sector for the successful and rapid implementation of research results in modern practice and management. The component quality of life and personality development implies a system of measures to provide comfortable, convenient and safe living conditions, training and personality development for university stakeholders such as students, teachers and researchers.

\subsection{Importance of the Problem}

Digital transformation is becoming global in nature, and the Russian Federation is well placed with all the capabilities and potential to become a leader. According to the rating of countries by the index of development of the digital economy (Shaposhnik et al., 2018, p. 16), Russia takes 23rd place and is ahead of a number of countries in Eastern Europe, such as Poland, Hungary, Romania and Bulgaria, and Greece and Cyprus in Southern Europe. Russia has values below the average index of development of the digital economy, and shares a group of countries with Italy in their level of development of the digital economy.

In the context of higher education globalization, universities enter the competition on the world stage (Gafurov et al., 2014; 2017). In such conditions, the competitiveness of a university will be determined by the timeliness of introduction of new technologies, the level of the main types of activity digitalization, readiness to transform the infrastructure for the development of the new generation educational system (Maltese, 2018; Kryukov et al., 2017).

Universities recognized as centers of the spheres of education, science, research, culture, should become advanced areas for the introduction of new digital technologies, while acting as the main factors and institutions that contribute to the further process of digitalization of the economy (Order of the Government of the Russian Federation of July 28, 2017 No. 1632, 2017; The development of the digital economy in Russia. Program until 2035, 2017).

One of the tasks universities have is to create new demanded knowledge and help people to adapt effectively to changing conditions. One of the factors for people to meet the requirements of the digital work environment and the knowledge society is to increase the digital literacy of the population (Salisbury et al., 2019). In this regard, educational organizations should strive for a wider use of digital technologies in their activities. Together with all parties concerned in the field of education, modern universities will strive to create a strategy of not only digital learning, but also a digital culture, and a digital educational platform that will systematically use, expand and implement the possibilities of digital media to provide high-quality education (The development of the digital economy in Russia. Program until 2035, 2017). Within these conditions, the university becomes the central link that 
sets the pace of digital transformation of technological and social systems (Safiullin and Elshin, 2019; Volkov, 2009). Therefore, the university should be able to respond to challenges for the most promising and rapidly developing industries, solving tasks that are important for society, tasks that are important for the development of the country, economy and industry, that were unable to be solved by previously created and existing structures, institutions and industry. A modern university should not only respond to external and internal changes in a completely different way, but in some areas should foresee and anticipate them. It should be adaptive in the direction of increasing its competitiveness.

The problem of modern Russian higher educational institutions is that both management mechanisms and the basic principles of organizing university infrastructure are those laid down mainly in the middle of the last century (Mitrofanova et al., 2019; Puzanova et al., 2019). To ensure the competitiveness of today's university, it is necessary to absolutely change the management mechanisms and their infrastructure. One problem is that it is impossible to clearly articulate what a modern university should be like, and what future markets are going to be in order to set clear-cut requirements for what a digital university should be like. In the context of the digital transformation of the economy and society, new demands are placed on universities as one of the most important links in the education system. The important question is: who can best formulate the requirements for university infrastructure?

By way of illustration, the following section explores the influence groups and interests of the main stakeholder groups:

1. A student, studying as a main stakeholder or one without whom the meaning of the educational activities of the university may be lost. Entering the university, students have certain expectations and visions regarding their future and career. One of the main goals for students is successful employment with competitive remuneration. Therefore, the following requirements are presented to the university: communication with the real sector, the opportunity to take internships in large companies in the region, and the developed infrastructure of the university.

2. The university itself: its teachers, researchers and scientists, service and administrative staff.

University staff are interested in a competitive salary and a constructive free creative environment that allows them to create and invent. Currently, the earnings of university employees are increasingly dependent upon the results of their scientific and innovative activities such as winning contests, securing grants and business-contractual activities. The success of research and innovation activities of the faculty depends on the degree of integration the university has into the global innovation system including joint research, collaborations, and mirror laboratories. It is important to ensure close integration of the university with the real sector of the economy, which will ensure the flow of relevant contractual work and increase the well-being of employees.

3. External government: Ministry, Federal Education and Science Supervision Service, development institutes, region, city.

There exist a number of contradictions inherent in this level. State bodies are interested in improving the quality of education and graduates which determines the orientation of the state educational policy towards the comprehensive development of universities at a global competitive level. The state is forced to spend significant resources on financing basic science and priority research and innovation developments through the operation of a network of grant and competitive funds. Due to limited budget resources, priority areas of science and technology are being formed that receive priority financing. This situation causes the conservation of other breakthrough areas that could unexpectedly bring Russian universities to a higher level of competitiveness. Another contradiction lies in providing open access to information and knowledge to the latest discoveries and inventions, to accelerate the country's innovative development, and it makes it necessary to maintain state secrets in certain breakthrough areas of science and technology. Another contradiction is that government bodies are interested in the high quality training of graduates, and it is important that graduates, after receiving a quality education, do not stay to work in other countries. The better the students are trained, the more competitive they become, and accordingly, they will strive for a higher level of remuneration, and government bodies cannot always provide this.

4. Enterprises, companies, business environment.

Stakeholders such as enterprises, companies, and business are primarily interested in obtaining qualified personnel trained by universities. To this end, in the traditional model of higher education, along with theoretical training and research work, production and undergraduate practices are provided. However, this format of training in modern conditions also needs to be improved. Taking into account the infrastructural logic, enterprises and organizations of a certain territory should have access to the general world personnel potential. Accordingly, university graduates should have global personnel competitiveness, which also depends on the degree of development of the university 
infrastructure at the level of international standards. Another factor in solving this problem is the cost of human resources and the desire of enterprises and organizations to invest in the education of their employees. At the crossroads of the above tasks, there should be a state coordinating and helping to meet the staffing needs of enterprises and organizations.

Considering the positions of the main groups of university stakeholders, even they in a dynamically changing environment, cannot have a clear idea of the key characteristics of the university of the future. Therefore, it is no longer the infrastructure design what matters, but the clear-cut principles and requirements within which management and university infrastructure should be built.

\subsection{Literature Review}

Theoretically the study is based on the results of modern research by leading domestic and foreign scientists who have devoted their works to improving the strategic development and digitalization of the university (Suryadi, 2019; Öztürkler, 2017; Lezer et al., 2020).

Every year, more authors, scientists and researchers are paying attention to the issues of digital transformation of the main activities of the university. The digital transformation, which has allowed the largest universities to make a quantum leap in development, is becoming a key factor in ensuring the competitiveness of the university in the new digital era (Gama, 2019; Herri et al., 2019; Khalid et al., 2018; Maltese, 2018; Perez Gama et al., 2018; Faria et al., 2017).

Universities are central to the global digital transformation (Xiao, 2019; Sirotkina et al., 2019). The main directions of global digital transformation are integrated into all areas of the university's activity strategy. Shared knowledge resources become a reliable basis for decision making throughout the life cycle of infrastructures. In this regard, many universities are introducing information modeling structures for buildings, premises, campus (BIM). Among them are the University of Minho (UMinho). Research by Cruz and Azenha, (2018) briefly describes the main stages of the implementation of this structure, which are relevant to achieve this goal, in particular from the point of view of features of facility management.

In the digital age, the importance of intellectual capital and knowledge management to survive in the face of growing competition has increased. Therefore, in recent years, the central object of many modern studies has become personnel as the carrier of the company's human capital (Gander et al., 2019). Another important component of the management system is knowledge management, which makes it possible to systematize and integrate knowledge and disseminate it in all departments of the organization. Taghizadeh and Shokri's (2015) research into the study of knowledge management infrastructure at the Azad Islamic University in Tabriz, where 460 people were surveyed, reported that the knowledge management infrastructure in organizations was relatively favorable (Taghizadeh and Shokri, 2015).

The evolution of society has led to a significant increase in the amount of data stored by organizations (Anica-popa, 2011). The rapid development of technology has made it possible to analyze a large amount of data, structure them and identify among them the most valuable and important for supporting management decision-making processes. Examples of such systems are DSS and the use of BI architectures. As most of the services provided by modern companies are supported by IT infrastructure, it is important that they are suitable and able to maintain the adequate functioning of the main functional units of the organization. Taking into account the above priorities, research by Branco, Martins, Gonçalves, Bessa and Costa (2015) considered it important to conceptualize the creation of a decision support system for the university's IT infrastructure. To achieve this goal, the Services of Information and Communication (SIC) of the University of Tras-os-Montes and Alto Douro (UTAD) were used. Due to the introduction of this decision support system, the SIC / UTAD have increased their ability to make more grounded and informed decisions, optimizing and thereby more efficiently managing the UTAD IT infrastructure (Branco et al., 2015).

The modern educational space sets new requirements for the quality of educational and information services demanded by university students and staff, users and employees of enterprises, and government officials (Korableva et al., 2019; Merzon et al., 2017; Galimullina et al., 2020; Sayabek et al., 2017). Wang and Ru (2013) developed an infrastructure project for a university information services platform using data warehouse technology. The method of integrating information resources proposed by Wang and $\mathrm{Ru}$ (2013) allowed the university platform to implement an object-oriented, multi-tiered service to meet user service requirements and support decisions. 


\subsection{Hypotheses of Research}

After analyzing the main expectations of the user groups, the following requirements for managing a university's infrastructure logic is proposed:

1. Accessibility is the property of an object to be suitable for timely use. Modern universities should work seven days a week and twenty-four hours a day. Moreover, digital technologies allow this to be done. In addition, this will allow a quick response to changes in the external environment and ensure high competitiveness.

2. Universality. The universality property implies the suitability of the university's services and products for most users, or provision of a specialized variety of service or product for each user group.

3. Standardization - compliance of the services provided by the university with international or domestic standards.

4. Scalability is the ability to increase productivity in proportion to additional resources. Scalability can be estimated through the ratio of the increase in performance of the system to the increase in resources it uses.

5. Focusing on the priorities of products and services created and provided by the university can contribute to the university's competitiveness.

6. Multiculturalism is a policy aimed at the preservation and development of cultural differences, and the theory or ideology justifying such a policy.

All of the above suggestions impact not only on infrastructure, but infrastructural logic. As there is no clear vision regarding the infrastructure of universities of the future, the project proposed is to be guided by the principles of infrastructure logic.

The new principles of university management have identified the main tasks of digital transformation:

- creating a system of preventive training and staff development;

- creating a comfortable environment for the work and development of employees;

- creating a system of new knowledge, taking into account the needs of future markets;

- improving the technology transfer ecosystem.

The purpose of this work is to reveal the principles and requirements for improving the university infrastructure using digital technology.

\section{Methodology}

The methodology of this study was based on the method of modeling a university management system. At the core of the model was the concept of infrastructure logic, which included new elements in the university management infrastructure: university stakeholders, cultural values, investments and translation.

The methodological basis of the study was a systematic approach to the analysis of the phenomena and approaches under consideration (O'Connor, 1997; Blauberg et al, 1970). The study was based on the wide use of abstract-logical, systemic and comparative methods, methods of analysis and synthesis, scientific abstraction, methods of consistency and complexity (Shchedrovitsky, 1981). Such methods made it possible to generalize the existing practice of using digital technologies in universities and offer recommendations for improving their infrastructure.

The study presented methodological approaches to organizing and improving access control for various types of university infrastructures, including premises, equipment, teachers and scientists, information services, cultural values, investments, and other benefits of life quality. The authors of the study proposed key performance indicators for each type of university infrastructure, which more adequately characterized the level of digitalization of the university in modern conditions.

\section{Results}

When formulating requirements for a modern university, it was important to initially determine, what was the university associated with among various groups of stakeholders and why. Traditionally, students who come to study after school, treat the university as the stage of life necessary for further successful employment. Therefore, the employer should be included in the process of training a specialist at all stages of the educational process. Topics for graduate qualifications should be determined by employers. New educational programs are created only when it is in demand by employers. The employer should be ready to offer students a base of practice and provide real support in implementing the educational program in cooperation with the university.

However, the environment is changing so dynamically that neither society, nor enterprises, nor the real sector, nor the 
university itself can clearly say: what is the digital future going to be and what the competitive infrastructure should be like? In this regard, the mobilization of a significant number of resources is required (Bruckmann, et al., 2018; Nguyen et al., 2019; Poleman et al., 2019; Silva et al., 2018). The university's largest stakeholders, cultural values including formal and informal rules of conduct, traditions, brand, reputation, investments and translation, should become integral parts of the infrastructure logic.

Digital transformation involves a series of technological, managerial and organizational transformations. Digital transformation includes not only the use of the latest technologies, but also provides opportunities for the provision of services and the ability to ensure the supply of goods, to make available large amounts of data, regardless of the actual availability of material resources, creating new connections between people and places. Along with new features, digital transformation brings new challenges for the university's IT infrastructure, and over time, it has an increasing load (Maltese, 2018).

The list of infrastructure management objects was completed with the concepts of cultural values, investments, translation, the addition of which allows transforming the infrastructure management processes and introduction of a new concept of infrastructure logic (Table 1).

Table 1. University resource list transformation

\begin{tabular}{cc}
\hline Traditional university resource list & Offered university resource list \\
\hline Resource management: & Managing access to university infrastructure objects: \\
Infrastructure: & Infrastructure: \\
- campus, buildings, structures, premises; & - campus, buildings, structures, premises; \\
- service lines and communication; & - service lines and communication; \\
- equipment and materials; & - equipment and materials; \\
- teachers and researchers; & - teachers and researchers; \\
- information resources and services; & - information resources and services; \\
- other infrastructure facilities. & - other infrastructure facilities. \\
& + cultural values; \\
& investments (the ability to mobilize resources for the \\
& implation of projects); \\
& + translation (the ability to convert scientific and \\
& educational competencies into scalable projects in the \\
& real sector);
\end{tabular}

The effectiveness of a modern university is determined by its role in advanced scientific research, educational technologies, training processes and the commercialization of its intellectual potential. Using digital technologies, the university provides prompt, mutually beneficial access to its resources, while simultaneously gaining access to the resources of other partner universities. In this regard, we list the promising tasks of a modern university:

1. Improving the communication system within the university;

2. Achieving common cultural values for different groups of university users;

3. The solution of scientific, educational and technological problems using digital technology. The digital infrastructure represents the countenance of the university, its strengths, which have been formed due to a focus on development priorities.

Access for a specific user is carried out within the User Group, i.e. for the user to receive certain rights, it is 
necessary to include them in the group with the desired level of rights. If a user is a member of several groups, then their access level is determined by the sum of the rights of these groups. The list of access rights to each of the university's assets should be regulated. Timely and high-quality access to university assets is very important for both external and internal users. Of interest is the presentation of the interpretation of access to resources in the context of the basic elements of the university infrastructure.

For each of the university's infrastructure facilities, principles and requirements were formulated for access control:

1. Premises access control. An important principle of managing access to premises should be ensuring timely access. The creation of a unified digital platform for managing access to university infrastructure will make it possible to optimize and automate access processes. In most cases, student access to the premises is provided by the teacher. This model has emerged from the time when the main components of the educational process were the teacher and students. In a modern university, students should have access to the premises automatically. The university's unified access control system should include information on the classroom schedule, the list of groups, and the system should know in which classroom which student should be. It is enough for the student to authenticate using one of the methods such as RFID-identification, identification using a campus card or bio-identification using a fingerprint or iris in order to gain access to the room. By entering the room, the student gets the opportunity to start working with equipment and training materials. The technological equipment of the room can be adjusted so that video lectures or presentations begin to be displayed from the moment the lesson begins.

Attendance accounting and stimulation of compulsory attendance can be provided by introducing radio frequency RFID identification or identifying the student's presence in the classroom using a campus card. Additionally, there is no need to control teacher attendance, but the disadvantage of this method of identification is that it is possible to transfer the campus card or RFID identifier to another student and thus bypass the authorization, identification and attendance system. Modern technologies provide the opportunity to organize access by bio-identification with the recognition of people by face, fingerprint or iris. There is some contradiction with the infrastructure logic described above. Tight control of class attendance is contrary to the principles of free access to university resources, which is dictated by infrastructure logic. However, such a contradiction takes place only at the initial stage. With the development of the necessary cultural values, the accumulation of investments and the beginning of the transfer of knowledge to the external environment, the control functions of modern technologies will become a minor matter. The most important will be the functions of ultrafast access to university resources. Control will become built-in and will be mediated by cultural values and established institutions (accepted rules of behavior for university stakeholders). Institutionalization of infrastructure logic will take place.

Based on the above, we have formulated KPIs for controlling access to premises:

1.1. The possibility to find a route to the required building and university room in one minute. The university's digital platform should be able to contextually search for classrooms. At the same time, the student does not need to remember the room number, it is enough to enter the number of his group, because the system should keep a schedule of classroom activities for the entire university.

1.2. It is proposed for university employees to organize the possibility of key-free access to their workrooms and classrooms (face, fingerprint or iris recognition). This will allow one not to waste time fetching the keys and automate the accounting (register) of the time and duration of employees in certain classrooms and in the university building.

1.3. For students in the digital age, a video broadcast can be a worthy analogue of attending a class, which will be very useful for those who cannot be in the room due to illness or other reasons. KPI provides instant access to the online broadcast of the class through a digital platform with the ability to view class recordings. Thus, the control of access to premises is reduced to controlling access to information that the user can receive to the same extent, regardless of attending the class.

2. Equipment Access Control involves preventive registering and inventory of university equipment in a digital map (register) in a unified digital university platform. One of the reasons for equipment breakdown is the inept use, therefore, quality control of access to the equipment should include preceding user training in equipment skills, and user testing before allowing a person to work with it.

We offer the following KPIs to control access to equipment:

2.1. Timely informing users about the equipment available at the university, its features, performance and technical characteristics. This becomes possible due to the fixation of each object and its features in the digital platform of the university. 
2.2. Supply of new equipment necessary for work within one week.

2.3. An opportunity to access the necessary laboratory of another university.

The user must be able to book research equipment via the Internet.

3. Managing access to teachers and scientists. Traditionally, students' access to teachers and scientists of the university is organized through classrooms, individual consultations in the framework of research project. The development of digital technologies makes it possible to organize online consulting and even conduct online classes for students.

We offer the following KPIs to control access to teachers and scientists:

3.1. The ability to receive information on time, place and format of consultation with a teacher in a timely manner through a digital platform and register for a consultation in one click.

3.2. In the digital platform, it is necessary to keep records of all teachers and scientists and keep up-to-date information on their latest research, developments and courses.

4. Access to information services control. The traditional procedure for accessing information services involves authorizing a user in the system by entering a username and password. In modern times, this is more of a burden on the user and complicates access to resources. The user has to remember passwords from different systems, as different services have different length requirements and a set of required characters. The system is not perfect in that another person can accidentally or intentionally get to know the password and take advantage of the user's resources. Therefore, it is proposed to make the transition to access using bio-identification of a person. In our opinion, authorization should be as convenient as possible for the user, once he has logged in at the entrance to the system, other resources should not require re-authorization.

We offer the following KPIs to control access to information services:

4.1. Convenient instant access to all university information services: electronic libraries, databases, etc., convenient interface and navigation system.

4.2. Increasing the number of information services with information available in the digital platform of the university.

5. Cultural values access control. Cultural values are irreplaceable material and intangible objects and cultural works created by a person as a result of the creative process, having artistic and property value, universal significance and bearing an aesthetic, scientific, historical impact on a person (Neshatayeva, 2009; 2013).

Cultural values also include a collection of university activities that a user can or should attend. Timely and complete information about upcoming events will allow users to better navigate and take part in the cultural life of the university. It is supposed to connect all users of the university to a single digital platform, so the user in his personal account can observe the specially compiled calendar of events he would be most interested to visit.

Access to cultural values should include information support and user support on cultural objects.

The authors propose the following KPIs to control access to cultural values:

5.1. The number of university events with information available on the university's digital platform.

5.2. The ability to instantly inform the user of the digital platform about all the possible activities of the university and connect to participate in them within one minute. Online participation should be provided.

In accordance with this, the principles, management mechanisms and infrastructure of the university should be transformed.

The new principles of university management should be as follows:

- meritocracy - the principle of management, according to which leading positions should be occupied by the most capable people, regardless of their social origin and financial wealth (Adler, 2017);

- autonomy and publicity of management;

- product diversity of management results;

- individualized educational trajectories and programs.

Promising cultural values consistent with infrastructure logic will bring about concepts of mutual assistance, cooperation and partnership. In the future, these cultural values will become indispensable in providing access to 
university resources. All university stakeholders will seek to obtain these cultural values, since the effectiveness of their personal, economic and social activities will depend on this. We must create such an infrastructure that every stakeholder can receive and mutually enrich the cultural values of a modern university, according to the infrastructure logic. In other words, cultural values should attract people with new ideas and give them the opportunity for self-realization through access to university resources. Access to cultural values will occur automatically if a person accepts these cultural values and participates in the university's cultural events.

6. Investment access control. Digitalization provides new opportunities for promptly attracting investment for the implementation of a project. If an employee or student of a university has a good idea, then it should be possible to find resources for its implementation, that is, to find resources not only financial, but also to find a team of like-minded people, and a team of users (Akhmetshin, 2019).

Based on the above, we have formulated KPIs for investment access control:

6.1. The ability of users to get an expert assessment of the investment attractiveness and prospects of their project within 1 day.

6.2. The number of projects and initiatives that have received investment support.

6.3. The number of users who have successfully implemented their project after receiving expert assessment and investments with the support of the university;

6.4. The total amount of investment funds received by all the university users for the implementation of their projects;

6.5. Average profitability of investment projects of the university users.

7. Access to other quality of life benefits. This category includes all those objects that were not included in the previous ones. For example, access to university vehicles (if available) or to sports facilities. No matter what the infrastructure object is like or what it is, universal principles for managing access to objects can be formulated:

7.1. The availability of information about the infrastructure in a single digital platform of the university. The information should include the period(s) of time in which the user can use this object (based on the category of users to which it belongs).

7.2. Possibility of online-booking access to the facility for a certain period of time (if appropriate).

It is important to ensure the harmonious development of a student in everything. For this purpose, the university infrastructure should include: a set of sports facilities and gyms, healthcare facilities, a security service, etc. It is necessary to create such an infrastructure that could provide one not only with a decent education, but also with the opportunity of all-round development.

Summing up, it is important to note that when talking about access control, it is not only about providing or not providing access, but namely about control, that is, providing quality user support when working with the system and infrastructure objects, in order to achieve certain results. Access control quality should be measured by performance indicators. Performance, in turn, affects the image of the organization.

\section{Discussion}

Issues of managing access to infrastructure facilities of organizations (including educational ones) are widely discussed in the scientific literature.

As the literature review has shown, two areas of discussion of this issue are developing: firstly, technical and information and communication tools for accessing university infrastructure are being investigated and tested, and secondly, recommendations are formulated to improve the cultural values of the university in the digitalization era, to attract investment in higher education school to accelerate the translation of knowledge into the real sector of the economy.

Consider the first line of discussion. Today, all over the world, a digital, non-contact method of data transmission is the main channel for the exchange of information. The total conversion of information into a digital format and its release from a material medium opens up many new opportunities for users, but at the same time, many technical and functional problems arise. These problems affect most business sectors. Among them, university management includes the administration of the educational process, financial management and registration fees and access rights to various university services and infrastructure facilities. Security today is one of the main problems in the world of digital information. According to researchers Ghizlane, M., Reda, F.H., Hicham, B. (2018), smart cards are identity carriers that fully contribute to ensuring access security through strong authentication. In their study, they propose 
building an architecture based on the use of smart cards and public key infrastructure (PKI). This will provide simultaneous and secure access for different users (student, teacher and administrator) with different levels of classification to different objects of the university infrastructure (Ghizlane et al., 2018; Neshatayeva, 2009).

The development of technology has led to a significant increase in the amount of data and digital information. In the field of digital information management, security and control issues are fundamental ones, access control and management issues being critical. These issues always require an effective and timely solution. One of the modern directions in solving such issues is block chain. Block chain is an effective technology that provides maximum security, trust and maximum access control in large data systems. In the block chain network, information is stored in the form of a distributed registry, which ensures the security of data storage. In a block chain network, it is impossible to completely hide, delete, or distort a previously recorded information block, because information is not stored in one, but in several places at once. Researchers Sifah, Xia, Agyekum, Du, Guizani (2018) suggest using an independent block chain based on a chain in which a virtual container is created in which the parties can make transactions. At the end of the transaction, the results are stored in an independent block chain network, which significantly reduces the amount of data stored. The effectiveness of the system proposed by the authors exceeds the existing ones (Sifah et al., 2018; Adler, 2017).

A fundamentally new access control model for large infrastructures was proposed by the researcher Mammass (2019). The S-OrBAC (Service-Organization Based Access Control) model is based on two fundamental concepts: organization and service. With the growth and development of the organization, consolidation of the infrastructure and expansion of user communication with various types of resources and data, the need for access control and management systems increases. The author offers his general view of the service concept in large infrastructures and considers various entities of the S-OrBAC model. The study examined an example of the use of the model in the management of a university that provides numerous educational services (Mammass, 2019).

Consider the second line of discussion. In our model of infrastructural logic, a special place is occupied by cultural values, on which the effectiveness of access control to university infrastructure will largely depend. According to researchers, in a special cultural atmosphere that motivates active innovation and is based on high moral standards, the process of acquiring professional experience and gaining advanced knowledge and skills is more active (Sergeeva et al., 2018). Digitalization enhances these processes and allows for quick access to the university infrastructure.

The motivation of students to use the possibilities of digitalization is affected by the level of quality of life of students and the level of comfort of living and learning. Researchers also note opposing trends. High quality of life provides high satisfaction with the educational process. Accordingly, digitalization, as an accelerator of access to university infrastructure, also has positive effects on the educational process and student motivation (Rezaee et al., 2019).

The fairly successful results of digitalization of Russian universities, building a model of access control to infrastructure, are the result of a general positive trend in improving the quality of life of students (Valkova, and Komarovskaya, 2019). Accordingly, this confirms our idea that the quality of life should be considered as the most important element of the new paradigm of infrastructure logic. A special place in the structure of the concept of quality of life should be given to the physical health and active sports of students and university teachers. The research results show that the quality of life depends entirely on an active lifestyle, and this, in turn, is a certain culture of behavior (Çiçek, 2018). Thus, the point about the need to include cultural values in infrastructure logic is once again confirmed.

Another important aspect of the existing discussion is the effects that arise when improving the quality of life of students, increasing the comfort of living and the conditions of joint research activities. As researchers note in the digital age, it is extremely important to ensure that students form such competency as teamwork (Shchedrovitsky et al., 2018). These results confirm the shift in the modern paradigm of higher education to joint, cooperative work, the use of a common university infrastructure, and ensuring effective access control to it.

\section{Summary and Conclusions}

In the conditions of rapid development of technologies, digitalization of many areas of life and society, changes in the system and infrastructure of educational organizations are inevitable. In modern conditions, the university has to meet new requirements. The speed of reaction to external and internal changes, the flexibility and adaptability of the university in the new digital era should fundamentally increase. However, the current management system and infrastructure has formed in the past era and does not meet the emerging requirements. In the digital era, the 
requirements for university management and infrastructure are changing dramatically. Digital infrastructure objects such as digital educational content, electronic libraries, distance technologies, etc. are added to familiar objects. The importance of developing digital infrastructure for increasing the competitiveness of the university is growing. An increase in the number of university infrastructure facilities requires effective control of user access to them.

The purpose of the study was to disclose the principles and requirements for university infrastructure access control.

The study presents methodological approaches to organizing and improving access control for various types of university infrastructure: premises, equipment, teachers and scientists, information services, cultural values, investments, as well as other benefits of quality of life.

The authors have investigated the positions of the main groups of university stakeholders, and based on this, they offer the requirements for managing the university's infrastructure logic, the new principles of university management and determine the main tasks of digital transformation.

The authors propose a new approach to managing infrastructure logic, which involves shifting the focus from asset management to managing access to university infrastructure.

The contradiction between the current state of infrastructure and new requirements is proved, and on this basis a new management concept called infrastructure logic is formulated.

The authors have formulated principles, requirements and new KPIs for access control for each of the university's infrastructure facilities.

Practical and social implications. To ensure the harmonious development of students, the university infrastructure should include new components: a set of sports facilities and gyms, healthcare facilities, a security service, etc. It is important to create such an infrastructure that could provide one not only with a decent education, but also so that the user has the opportunity to diversify.

Summing up, it is important to note that access control assumes the provision of high-quality user support when working with the infrastructure system and facilities, in order to achieve certain results. Access control quality should be measured by performance indicators. Performance, in turn, affects the image of the organization.

The presence of an effective mechanism for managing infrastructure logic allows for the improvement of the communication system within the university; achievement of common cultural values (the presence of similar values for different groups of university users); critical infrastructure will contribute to solving scientific, educational and technological problems.

The main difficulty in further research is the need to implement infrastructure logic at the state level. Government policies for the development of the digital economy should include a new methodology for the transition from resource management to access control. The difficulty lies in the fact that the subjects of government are motivated to maintain the existing situation and are interested in maintaining control over resources. Overcoming this contradiction is only possible with the development of the principles of democracy and effective civil society institutions.

In this regard, a promising scientific research is the development of measures to improve the institutions for stimulating innovation and creative activity for the transition to infrastructure logic and a new access control paradigm.

\section{Acknowledgements}

The reported study was funded by RFBR, project number 19-29-07037.

\section{References}

Adler, Yu.P. (2017). Japanese way of motivation: what does it give us?. Quality Management Methods, (12), 10-14.

Akhmetshin, E. M. (2019). Digital transformation of university infrastructure: development of a complex of new principles and requirements. Ekonomika i menedzhment sistem upravleniya, 4.1(34), 110-115.

Anica-popa, I. (2011). Development life cycle of the organizational memory for accounting domain. Paper presented at the Creating Global Competitive Economies: A 360-Degree Approach - Proceedings of the 17th International Business Information Management Association Conference, IBIMA 2011, 4, 1296-1298.

Bahrani, S., Elmabrok, O., Lorenzo, G. C., Ghalaii, M. \& Razavi, M. (2019). Quantum and classical communications on shared infrastructure. Paper presented at the International Conference on Transparent Optical Networks, 2019-July. https://doi.org/10.1109/ICTON.2019.8840309 
Blauberg, I. V., Sadovsky, V. N. \& Yudin, E. G. (1970). System approach in modern science. Problems of the methodology of system research. Moscow: Thought, 7-48.

Branco, F., Martins, J., Gonçalves, R., Bessa, J. \& Costa, A. (2015). A decision support platform for IT infrastructure management: The university of Trás-os-Montes e Alto Douro services of information and communications case study. 2015 10th Iberian Conference on Information Systems and Technologies, CISTI 2015, art. 7170492

Bruckmann, S. \& Carvalho, T. (2018). Understanding change in higher education: An archetypal approach. Higher Education, 76(4), 629-647. https://doi.org/10.1007/s10734-018-0229-2

Buyak, B., Tsidylo, I., Kozibroda, S. \& Repskyi, V. (2019). Ontological model of representation of university resources. Paper presented at the CEUR Workshop Proceedings, 2393, 29-40.

Çiçek, G. (2018). Quality of life and physical activity among university students. Universal Journal of Educational Research, 6(6), 1141-1148. https://doi.org/10.13189/ujer.2018.060602

Courcoubetis, C. \& Weber, R. (2012). Economic issues in shared infrastructures. IEEE/ACM Transactions on Networking, 20(2), 594-608. https://doi.org/10.1109/TNET.2011.2163824

Cruz, P.J.S. \& Azenha, M. (2018). The challenges of adopting BIM for setting and infrastructure management of University of Minho. E3S Web of Conferences, 48, 02002

Faria, J. A. \& Nóvoa, H. (2017). Digital transformation at the university of Porto. Lecture Notes in Business Information Processing, 279, 295-308. https://doi.org/10.1007/978-3-319-56925-3_24

Gafurov, I. R., Safiullin, N. Z., Safiullin, L. N. \& Odintsova, J. L. (2014). Education system of the world: Modern trends. Mediterranean Journal of Social Sciences, 5(18 SPEC. ISSUE), 91-94. https://doi.org/10.5901/mjss.2014.v5n18p91

Gafurov, I., Safiullin, M. \& Elshin, L. (2017). Mechanisms of higher school development in the paradigm of its global competitiveness (on the example of the Kazan Federal University). Revista QUID (Special Issue), 1495-1500.

Galimullina, E., Ljubimova, E., \& Ibatullin, R. (2020). SMART education technologies in mathematics teacher education - ways to integrate and progress that follows integration. Open Learning, 35(1), 4-23. doi:10.1080/02680513.2019.1674137

Gama, J. A. P. (2019). Intelligent educational dual architecture for university digital transformation. Paper presented at the Proceedings - Frontiers in Education Conference, FIE, 2018-October. https://doi.org/10.1109/FIE.2018.8658844

Gander, M., Girardi, A. \& Paull, M. (2019). The careers of university professional staff: A systematic literature review. Career Development International, 24(7), 597-618. https://doi.org/10.1108/CDI-07-2018-0191

Ghizlane, M., Reda, F. H. \& Hicham, B. (2018). A Security Policy for Access Control to Academic Services Based on Public Key Infrastructures and Smart Cards. International Conference on Multimedia Computing and Systems -Proceedings, 2018-May, 8525978

Hasanović, A., Mujčić, A., Suljanović, N., Pjanic, E., Samuelsen, D., Thyberg, B. \& Graven, O. H. (2012). Improving higher education with the cloud infrastructure: Information system requirements analysis for a modern global university. Paper presented at the 2012 15th International Conference on Interactive Collaborative Learning, ICL 2012, https://doi.org/10.1109/ICL.2012.6402154

Herri, Johan, A. P. \& Handika, R. F. (2019). Digital transformation: Insight from leaders in the mid-rank universities in Indonesia. Paper presented at the ACM International Conference Proceeding Series, 52-55. https://doi.org/10.1145/3371647.3371650

Holmwood, J. \& Marcuello Servós, C. (2019). Challenges to public universities: Digitalisation, commodification and precarity. Social Epistemology, 33(4), 309-320. https://doi.org/10.1080/02691728.2019.1638986

Huang, F., Teo, T., Sánchez-Prieto, J. C., García-Peñalvo, F. J. \& Olmos-Migueláñez, S. (2019). Cultural values and technology adoption: A model comparison with university teachers from china and Spain. Computers and Education, 133, 69-81. https://doi.org/10.1016/j.compedu.2019.01.012

Johnson, A. T. (2019). University infrastructures for peace in africa: The transformative potential of higher education in conflict contexts. Journal of Transformative Education, 17(2), 173-194. https://doi.org/10.1177/1541344618779561 
Kalitanyi, V. \& Bbenkele, E. (2018). Cultural values as determinants of entrepreneurial intentions among university students in cape town-south Africa. Journal of Enterprising Communities, 12(4), 437-453. https://doi.org/10.1108/JEC-01-2017-0017

Khalid, J., Ram, B. R., Soliman, M., Ali, A. J., Khaleel, M. \& Islam, M. S. (2018). Promising digital university: A pivotal need for higher education transformation. International Journal of Management in Education, 12(3), 264-275. https://doi.org/10.1504/IJMIE.2018.092868

Korableva, O., Durand, T., Kalimullina, O. \& Stepanova, I. (2019). Studying user satisfaction with the MOOC platform interfaces using the example of coursera and open education platforms. Paper presented at the ACM International Conference Proceeding Series, 26-30. https://doi.org/10.1145/3322134.3322139

Kryukov, V. \& Gorin, A. (2017). Digital technologies as education innovation at universities. Australian Educational Computing, 32(1).

Lezer, V. A., Shabatura, L. N. \& Karnaukhov, I. A. (2020). The flagship University's model in terms of digitalization: The case of industrial university of tyumen as a center of strategic decisions in the field of smart-city, IoT/IIoT and big data. Lecture Notes in Networks and Systems, 91, 387-396. https://doi.org/10.1007/978-3-030-32015-7_43

Lisyutkin, M. (2017). On possible reasons for university resource base decline. Voprosy Obrazovaniya, 2017(2), 74-94. https://doi.org/10.17323/1814-9545-2017-2-74-94

Maltese, V. (2018). Digital transformation challenges for universities: Ensuring information consistency across digital services. Cataloging and Classification Quarterly, 56(7), 592-606. https://doi.org/10.1080/01639374.2018.1504847

Mammass, M. (2019). An Access Control Model based on the concepts of Organization and Service for Large Infrastructures. Procedia Computer Science, 148, 571-579.

Merzon, E. E., \& Ibatullin, R. R. (2017). Architecture of smart learning courses in higher education. Paper presented at the Application of Information and Communication Technologies, AICT 2016 - Conference Proceedings, doi:10.1109/ICAICT.2016.7991809

Mitrofanova, Y. S., Sherstobitova, A. A. \& Filippova, O. A. (2019). Modeling the assessment of definition of a smart university infrastructure development level. Smart Innovation, Systems and Technologies, 144, 573-582. https://doi.org/10.1007/978-981-13-8260-4_50

Neshatayeva V. O. (2009). Cultural values in the human rights system. Russian justice, 7(39), 31-43.

Neshatayeva V. O. (2013). Cultural values: price and law. Moscow: House of the Higher School of Economics, $2013.118 \mathrm{p}$.

Nguyen, T. V. S. \& Laws, K. (2019). Changes in higher education teachers' perceptions of curriculum. Journal of Applied Research in Higher Education, 11(1), 76-89. https://doi.org/10.1108/JARHE-06-2018-0097

O'Connor, J. (1997). The Art of Systems Thinking: Essential Skills for Creativity and Problem Solving. United Kingdom: Thorsons.

Order of the Government of the Russian Federation of July 28, 2017 No. 1632 (2017, July 28). Retrieved July 31, 2019, from http://static.government.ru/media/files/9gFM4FHj4PsB79I5v7yLVuPgu4bvR7M0.pdf

Öztürkler, Z. (2017). Evaluation of technology strategies as quality strategy of higher education institutions. Eurasia Journal of Mathematics, Science and Technology Education, 13(7), 4021-4033. https://doi.org/10.12973/eurasia.2017.00770a

Perez Gama, J. A., Vega Vega, A. \& Neira Aponte, M. (2018). University digital transformation intelligent architecture: A dual model, methods and applications. Paper presented at the Proceedings of the LACCEI International Multi-Conference for Engineering, Education and Technology, 2018-July. https://doi.org/10.18687/LACCEI2018.1.1.274

Poleman, W., Jenks-Jay, N. \& Byrne, J. (2019). Nested networks: Transformational change in higher education. Sustainability (United States), 12(2), 97-99. https://doi.org/10.1089/sus.2019.29152

Puzanova, Z. V. \& Larina, T. I. (2019). Social dimension of students' problems under the development of the contemporary university infrastructure. RUDN Journal of Sociology, 19(4), 800-813. https://doi.org/10.22363/2313-2272-2019-19-4-800-813 
Rezaee, R., Pabarja, E. \& Mosalanejad, L. (2019). Students' academic quality of life and learning motivation in Iran medical university - pilot from south Iran. Pakistan Journal of Medical and Health Sciences, 13(2), 570-576.

Rothmann, S. (2013). Employee engagement in a cultural context. Employee engagement in theory and practice (pp. 163-179), https://doi.org/10.4324/9780203076965

Safiullin, M. R. \& Elshin, L. A. (2019). Role of higher school in the formation of the fourth industrial revolution in the Russian Federation. International Journal of Civil Engineering and Technology, 10(2), 1669-1676.

Salisbury, F., Hannon, J. \& Peasley, J. (2019). Framing the digitally capable university: Digital literacies as shared scholarly and professional practice. Paper presented at the ASCILITE 2017 - Conference Proceedings - 34th International Conference of Innovation, Practice and Research in the use of Educational Technologies in Tertiary Education, 152-157.

Sayabek, Z., Arzayeva, M., Gulbazar, M., Mustafina, A., \& Ulan, T. (2017). Key issues in relation to leading and managing educational change: Professional development in secondary school. Paper presented at the Proceedings of the 30th International Business Information Management Association Conference, IBIMA 2017 Vision 2020: Sustainable Economic Development, Innovation Management, and Global Growth, 2017-January, 4152-4160.

Sergeeva, M. G., Levkin, V. V., Kharnas, S. S., Musaev, G. K., Morokhina, S. L. \& Samokhvalov, A. V. (2018). Formation of teacher's innovative culture in the educational space of a medical university. Espacios, 39(21)

Shaik, F. F., Makhecha, U. P. \& Gouda, S. K. (2020). Work and non-work identities in global virtual teams: Role of cultural intelligence in employee engagement. International Journal of Manpower, https://doi.org/10.1108/IJM-03-2019-0118

Shaposhnik, S. B., Andreyev, A. I., Yelizarov, A. M., Yershov, P. S., Yershova T.V., Kalinko O.A., Katin A.V., Lebedev S.A., Raikov A .N., Semyonov Ye.V., Simakov O.V., Simachyov Yu.V., Khokhlov Yu.Ye. \& Yurevich M.A. (2018). National Digital Economy Development Index: Pilot Implementation. Moscow: Rosatom State Corporation.

Shchedrovitsky, G. P. (1981). Principles and general scheme of methodological organization of system-structural research and development. Moscow: Science, 193-227.

Shchedrovitsky, P. G., Filatova, M. N. \& Sheinbaum, V. S. (2018). Ontology of teamwork competency and approaches to its development at engineering university. Vysshee Obrazovanie v Rossii, 27(6), 71-82.

Shirokova, G., Osiyevskyy, O., Morris, M. H. \& Bogatyreva, K. (2017). Expertise, university infrastructure and approaches to new venture creation: Assessing students who start businesses. Entrepreneurship and Regional Development, 29(9-10), 912-944. https://doi.org/10.1080/08985626.2017.1376516

Shuter, R., Dutta, U., Cheong, P., Chen, Y. \& Shuter, J. (2018). Digital behavior of university students in india and the U.S.: Cultural values and communication technologies in the classroom. Western Journal of Communication, 82(2), 160-180. https://doi.org/10.1080/10570314.2017.1294703

Sifah, E. B., Xia, Q., Agyekum, K. O.-B. O., Du, X. \& Guizani, M. (2018). Chain-based big data access control infrastructure. Journal of Supercomputing, 74(10), 4945-4964

Silva, J. S., Peixoto, P. \& Freitas, A. (2018). Disparate faculty perspectives on system changes in higher education. Higher Education Research and Development, 37(3), 593-606. https://doi.org/10.1080/07294360.2017.1411338

Sirotkina, N., Syshchikova, E., Filatova, M., Greshonkov, A. \& Meshcheryakova, M. (2019). Directions of the transformation of companies and universities in the digital economy. Paper presented at the Proceedings of the 33rd International Business Information Management Association Conference, IBIMA 2019: Education Excellence and Innovation Management through Vision 2020, 8970-8975.

Suryadi, E. (2019). Communication management of digital information data in human resources as a policy making strategic program for university. Advances in Science, Technology and Engineering Systems, 4(4), 539-544. https://doi.org/10.25046/aj040465

Taghizadeh, H. \& Shokri, A. (2015). The study of knowledge management infrastructures in Islamic Azad university from faculty members' point of view (case study). Asian Social Science, 11(25), 39-47.

Tay, H. L. \& Low, S. W. K. (2017). Digitalization of learning resources in a HEI - a lean management perspective. 
International Journal of Productivity and Performance Management, 66(5), 680-694. https://doi.org/10.1108/IJPPM-09-2016-0193

The development of the digital economy in Russia. Program until 2035. (2017). Retrieved from http://spkurdyumov.ru/uploads/2017/05/strategy.pdf

Valkova, N. Y. \& Komarovskaya, E. V. (2019). Thirty-year trends in university students' lifestyle and quality of life. [Tridcatiletnyaya dinamika kachestva i obraza zhizni studentov vuzov] Gigiena i Sanitariya, 98(5), 534-539. https://doi.org/10.18821/0016-9900-2019-98-5-534-539

Volkov, A.E. (2009). Modern university. Prospects for Russia // Materials of the VI International Scientific and Practical Conference: "Education Development Trends: 20 Years of Reforms, What Next?". Moscow: Universitetskaya Kniga Literary Agency, limited liability company, 308-316.

Wang, X.G. \& Ru, J. (2013). Design and implementation of university information service platform based on data warehouse. Applied Mechanics and Materials, 321-324, 2543-2550

Xiao, J. (2019). Digital transformation in higher education: Critiquing the five-year development plans (2016-2020) of 75 Chinese universities. Distance Education, 40(4), 515-533. https://doi.org/10.1080/01587919.2019.1680272 